УДК 624.012.41:620.193.2

\title{
РОЗПОДІЛ КОРОЗІЙНИХ ПРОЦЕСІВ НА АРМАТУРІ ПЕРІОДИЧНОГО ПРОФІЛЮ ЗАЛІЗОБЕТОННИХ КОНСТРУКЦІЙ
}

Д-р техн. наук В.О. Бондар, канд. техн. наук Л.В. Бондар, старш. викл. В.О. Сушко

\section{РАСПРЕДЕЛЕНИЕ КОРРОЗИОННЫХ ПРОЦЕССОВ НА АРМАТУРЕ ПЕРИОДИЧЕСКОГО ПРОФИЛЯ ЖЕЛЕЗОБЕТОННЫХ КОНСТРУКЦИЙ}

Д-р техн. наук В.А. Бондар, канд. техн. наук Л.В. Бондар, старш. преп. В.А. Сушко

\section{DISTRIBUTION CORROSION PROCESS FOR REINFORCED STEEL PERIODIC PROFILE OF REINFORCED CONCRETE STRUCTURES}

Doct. of techn. sciences V.O. Bondar, cand. of techn. Sciences L.V. Bondar, Senior lecturer V.O. Sushko

У даній роботі використувавши двовимірне диференційне рівняння Лапласа, щяо описує дифузне поле кониентрачії анодних і катодних деполяризаторів, виявлені основні закономірності розподілу корозійного прочесу на арматурі періодичного профілю.

Розроблена математична модель яка з достатнім наближенням описує динаміку корозійного процесу на арматурі періодичного профілю. Показано, щз корозійні прочеси на арматурі призводять до вирівнювання профілю арматури.

Ключові слова: залізобетон, корозія, корозійцна стійкість, арматура.

В данной работе используя двумерное дифференциальное уравнение Лапласа, описывающее диффузное поле концентрачии анодных и катодных деполяризатора, выляллены основные закономерности распределения коррозионного прочесса на арматуре периодического профиля.

Разработана математическая модель, которая с достаточным приближением описывает динамику коррозионного прочесса на арматуре периодического профиля. Показано, что коррозионные прочессы на арматуре приводят к выравниванию профиля арматуры.

Ключевые слова: железобетон, коррозия, коррозионная стойкость, арматура.

In determining the service life of reinforced concrete structures in restoring structures that operate in aggressive environments, the question arises determining the degree of corrosion of reinforcement. In this work have used two-dimensional differential equation Laplace. It describes the diffuse field concentration anodic and cathodic depolarizers. The basic patterns of distribution of the corrosion process on a periodic profile reinforcement with depolarizer diffusion through concrete surface.

The developed mathematical model for reinforcement corrosion periodic profile. Model approximated describes the dynamics of the corrosion process. Periodic reinforcement profile makes her uneven surface in aggressive environments. As a result, there is an unequal distribution corrosive of currents. 
Chlorides is a standard aggressive environment for corrosion research reinforcement. Therefore, researches it has been used this environment. Since research shows that corrosion processes change the profile reinforcement. Profile of reinforcement leveled.

Keywords: reinforced concrete, corrosion, corrosion resistant fittings.

Постановка проблеми. За даними відомих російських спеціалістів із теорії залізобетону [1,7] думка про абсолютний захист арматури в бетоні залізобетонних конструкцій не вірна.

3 кожним роком спостерігається тенденція до підвищення ступеню агресивної дії середовищ на залізобетонні конструкції будівель i споруд. Це пов'язують 3 інтенсифікацією технологічних процесів, зі зростанням фонду будівель і споруд, запаси міцності будівельних конструкцій в яких значно зменшилися в результаті дії корозійних середовищ, широким використанням в будівництві конструкцій, що мають зменшену корозійну стійкість (попередньо-напружених, тонкостінних та ін.).

Аналіз причин ушкоджень залізобетонних конструкцій вказує на те, що переважною причиною виходу їх 3 ладу $\epsilon$ процес корозії сталевої арматури при доступі активуючих електролітів - розчинів солей та ін.

В даному випадку при виконанні відновлюваних робіт на залізобетонних конструкціях виникає питання визначення ступеня корозії арматури.

Як показали обстеження ряду залізобетонних конструкцій, що експлуатуються в таких умовах [4], періодичний профіль арматури приймає активну участь в розподілі корозійних ділянок на іiі поверхні. Тому виникає необхідність в дослідженні закономірностей корозії арматури періодичного профілю.

Формулювання цілі роботи. Виявити основні закономірності розподілу корозійного процесу на поверхні арматури періодичного профілю при дифузії деполяризатора (кисню) через бетонне покриття.

Аналіз останніх досліджень. Для оцінки атмосферної корозії арматури залізобетонних конструкцій використовуються емпіричні залежності $[6,8]$. Такі залежності дозволяють отримати наближені результати. Зважаючи на те, що корозія арматури в бетоні носить електрохімічний характер, ряд розробок зорієнтовані на використання електрохімічних $\mathrm{i}$ електричних параметрів при розрахунках корозії арматури. Так, в роботі [9] запропонований метод визначення розподілу корозії арматури залізобетонних конструкцій, що базується на використанні потенціодинамічних поляризаційних вольт-амперних характеристик і узагальненого закону Фарадея.

Грунтовими дослідженнями в [2] було доведено, що вологий стан бетону має вирішальний вплив на корозію арматури в залізобетонних конструкціях. Обмін середовища у поверхні арматури обмежений i може виконуватися лише за рахунок рідини i газів в капілярах і порах бетону. При відносній вологості повітря більше $80 \%$ корозія арматури в бетоні обмежена катодним процесом, тобто швидкістю надходження кисню до поверхні арматури. Тому в роботі [5] в якості базової була прийнята модель корозії, що враховує дифузійні процеси при надходженні кисню до поверхні арматури.

Математична модель корозії арматури в бетоні, що описане в роботі [11], також отримана на онові дифузійних рівнянь із балансу маси, балансу електричного заряду, енергетичного балансу, із врахуванням нерівності ентропії.

Виявлення не розв'язаних раніше частин проблеми. Загальним недоліком розроблених моделей корозії арматури $є$ те, що корозійний стан арматури не ув'язується із геометрією іiі профілю, що не дає можливості точно оцінити втрати площі перерізу при іiі корозії.

Виклад основного матеріалу. Вологій бетон $є$ провідником 2-го роду, тому процес корозії арматури у ньому можливо розглядати 3 позиції звичайної електрохімічної теорії корозії металів в електролітах.

Періодичний профіль арматури робить іiі поверхню не рівнодоступною по відношенню до компонентів електроліту, що призводить до суттєвих змін у розподілі корозійних струмів на поверхні арматури у поздовжньому напрямку.

Теоретичний аналіз корозійних процесів в даних умовах проведено на математичній моделі, у який границя фаз "бетон - метал" 
представлений у вигляді синусоїдального слабко вигнутого профілю:

$$
y=H \sin k x,
$$

де $H$ - амплітуда; $k=2 \pi / L ; L-$ період; $x, y-$ поточні координати. Причому $H k<1$.

Будемо вважати, що масоперенос анодних і катодних деполяризаторів у поверхні арматури, що кородує, визначаються дифузією, що на достатній відстані від межі фаз щільність струму постійна. При таких припущеннях у стаціонарних умовах задача зводиться до сумісного рішення двовимірних рівнянь Лапласа, що описують дифузне поле анодних і катодних деполяризаторів

$$
\Delta \vec{N}=0
$$

при наступних граничних умовах:

a) рівняння форми границі фаз

$$
y=H \sin k x ;
$$

б) умова сталих значень щільності струму на значній відстані від границі фаз

$$
\begin{aligned}
& -i=\sigma_{1} \frac{\partial C^{1}}{\partial y}=i_{\hat{e} \imath} \\
& -i=\sigma_{2} \frac{\partial C^{2}}{\partial y}=i_{\hat{e} \imath} \text {; } \\
& C^{1}=C_{a}=\frac{i_{\hat{e ̂ \imath} \partial}}{k \sigma_{a}}\left[V-h\left(-e^{-V}(A \cdot \sin k x+B \cdot \cos k x)+\sin k x\right)\right] ; \\
& C^{2}=C_{a}=\frac{i_{\hat{\imath} \jmath}}{k \sigma_{a}}\left[V-h\left(-e^{-V}(A \cdot \sin k x+B \cdot \cos k x)+\sin k x\right)\right],
\end{aligned}
$$

де $V=k y-h \cdot \sin k x$;

$h=k H, A$ i $B$ - сталі інтегрування.

Розподіл анодного корозійного струму по синусоїдальному профілю у першому наближенні має вид :

$$
i_{a}(x)=k \sigma_{a}\left(\frac{\partial C_{a}^{0}}{\partial V}+h \frac{\partial C_{a}^{1}}{\partial V}\right) \quad \text { при } \mathrm{V}=0
$$

в) умови поєднання процесів на поверхні поділу фаз

$$
\sigma_{1} \frac{\partial C^{1}}{\partial y}=\sigma_{2} \frac{\partial C^{2}}{\partial y}
$$

г) умова еквіпотенціальності поверхні арматури, потенціал якої дорівнюе стаціонарному потенціалу, $\mathrm{E}_{\text {ст }}$

В рівняннях (2-5):

$$
\begin{aligned}
& \Delta=\frac{\partial^{2}}{\partial x}=\frac{\partial^{2}}{\partial y} \text { - оператор Лапласа; } \\
& \mathrm{C}^{1}, \quad \mathrm{C}^{2} \quad-\quad \text { концентрації анодного } \mathrm{i}
\end{aligned}
$$
катодного деполяризаторів;

$\sigma_{1}=\mathrm{Z}_{\mathrm{a}} Д_{\mathrm{a}} \mathrm{F} ; \sigma_{2}=\mathrm{Z}_{\mathrm{\kappa}} Д_{\mathrm{K}} \mathrm{F} ;$

$\mathrm{Z}$ - заряд іонів, що дифундують;

Д - коефіцієнт дифузії відповідних деполяризаторів;

F - число Фарадея;

$\mathrm{i}_{\text {кор }}$ - середня щільність струму корозії;

$\frac{\partial C}{\partial n}$ - похідна по нормалі до профілю.

Рівняння (2) вирішувалось методом збурення, представляючи концентрації у вигляді рядів по малому параметру $\kappa H$.

запропонованими прийомами в [3], граничними умовами (3-5), отримано наступне рішення рівняння (2): 
визначення стаціонарного потенціалу на металі в умовах, коли анодні i катодні реакції визначаються дифузією [10]

$$
\begin{aligned}
& E_{\tilde{n} \grave{o}}=E_{a}^{0}+b_{a} \ln \frac{C_{a s}}{C_{a o}}, \\
& E_{\tilde{n} \grave{o}}=E_{k}^{0}+b_{k} \ln \frac{C_{k s}}{C_{k o}},
\end{aligned}
$$

де $\mathrm{E}_{\mathrm{a}}^{\circ}, \mathrm{E}^{\circ}{ }_{\mathrm{K}}-$ рівноважні потенціали анодного $\mathrm{i}$ катодного деполяризаторів;

$\mathrm{C}_{\mathrm{a} 5}, \mathrm{C}_{\mathrm{k} 5}, \mathrm{C}_{\mathrm{ao}}, \mathrm{C}_{\text {ко }}-$ концентрації анодних $\mathrm{i}$ катодних деполяризаторів у поверхні і в об'ємі розчину;

$$
b_{a}=\frac{R T}{Z_{a} F} ; b_{k}=\frac{R T}{Z_{k} F} .
$$

Після підстановки А і В у (8), отримаємо:

$$
i_{a}(x)=i_{\hat{\imath} \hat{\jmath}}(1+H k \cdot \sin k x) .
$$

Використавши закон Фарадея можливо виразити зміни за часом амплітуди профілю:

$$
-d H=\frac{M}{\rho \cdot Z_{a} \cdot F}\left(i_{\wedge}-i_{\vee}\right) d t .
$$

де $M$ і $\rho$ - молекулярна маса і густина металу, що розчиняється; $i_{\wedge}$ i $i_{\vee}$ - щільність струму розчинення металу на гребенях і між гребенями профілю; $Z_{a}$ - валентність іонів анодного деполяризатора; $F$ - число Фарадея.

Так як

$$
i_{\wedge}-i_{\vee}=[(1+H k)-(1-H k)] \cdot i_{\hat{\imath \imath} \delta}=2 i_{\hat{e ̂ \imath}} \cdot k H,
$$

то (11) можливо переписати в наступному виді:

$$
\frac{d H}{H}=-A \cdot d t
$$

де $A=\frac{M}{\rho \cdot Z_{a} \cdot F} \cdot 2 i_{\hat{e} \imath} \cdot k$.

Загальне рішення диференціального рівняння (12).

Після підстановки початкових умов $\left.H\right|_{t=0}=H_{0}$ і потенціювання, отримаємо:

$$
H=H_{0} \cdot e^{-A t},
$$

Якщо вважати, що товщина прокородованого металлу

$$
\delta=\frac{2 M}{\rho \cdot Z_{a} \cdot F} \cdot t
$$

To

$$
H=H_{0} \cdot e^{-\delta \cdot t} .
$$

Адекватність прийнятої моделі було перевірено експериментально на відрізках арматурних стрижнів періодичного профілю №36 по ГОСТ 5781-82. Коли арматура знаходиться в контакті із агресивним розчином, що накопичився в бетоні, то в таких умовах зберігається ряд загальних закономірностей, які відповідають корозії сталі при повному занурені в електролітичний розчин. Тому в якості корозійного середовища використано розчин $3 \% \mathrm{NaCI}$, у якому витримувалися відрізки арматурних стрижнів протягом 4-х місяців (2880 годин). Середня швидкість корозії арматурної сталі в 3\%-му розчині $\mathrm{NaCl}$ $-\mathrm{i}_{\text {кор }}=0,000003 \mathrm{~A} / \mathrm{cm}^{2}$.

На зразках були зняті профілографи до корозії та після витримки в корозійному розчині. Середня висота гребенів арматури до випробувань $\mathrm{h}_{\mathrm{r}}=2,0565$ мм, після випробувань - $\mathrm{h}_{\mathrm{r}}^{\prime}=2,0169$. Суттєвих змін у відліках на профілограмах між гребенями не спостерігалось. Тобто, спостерігався вирівнюваний ефект. В якості показника вирівнювального ефекту арматурного стержня вибрано відношення $\mathrm{h}_{\mathrm{r}}^{\prime} \mathrm{h}_{\mathrm{r}}$, яке в даному випадку складало

$$
\mathrm{h}_{\mathrm{r}}^{\prime} / \mathrm{h}_{\mathrm{r}}=2,0169 / 2,0565=0,98 .
$$

Згідно (14) в якості вирівнювального ефекту може бути вибрано

$$
H / H_{0}=1 / e^{\delta \cdot k} .
$$

Товщина прокородованого металу буде:

$$
\begin{gathered}
\delta=\frac{2 M \cdot i_{\hat{\imath} \jmath} \cdot t}{\rho \cdot Z_{a} \cdot F}=\frac{2 \cdot 56 \cdot 0,000003}{8,7 \cdot 2 \cdot 26,8} \cdot 2880=0,0021 ; \\
k=\frac{2 \pi}{L}=\frac{2 \cdot 3,14}{0,14}=15,3 ;
\end{gathered}
$$


$\delta \cdot k=0,0021 \cdot 15,3=0,032$.

Тоді

$$
\frac{H}{H_{0}}=\frac{1}{e^{0,032}}=0,97
$$

Таким чином, значення вирівнювального ефекту, отримане за прийнятою моделлю i експериментально мало відрізняються.
Висновки. На розподіл корозійного струму суттєвий вплив має геометрія арматурного профілю.

Теоретично i експериментально підтверджено, що в умовах низькопотенціальної корозії на арматурному профілі спостерігається ефект вирівнювання повехні.

Розроблена модель 3 достатнім наближенням може характеризувати реальний корозійний процес на арматурному періодичному профілі.

\section{Список використаних джерел}

1. Алексеев, С.Н. Коррозия и защита арматуры в бетоне обычных и предварительно напряженных железобетонных конструкций [Текст] / С.Н. Алексеев // Защита строительных конструкций от коррозии. - М.: Гостройиздат, 1961. - С. 25-39.

2. Алексеев, С.Н. Долговечность железобетона в агрессивных средах [Текст] / С.Н. Алексеев, Ф.М. Иванов, С. Модры, П. Шиссель. - М.: Стройиздат, 1990. - 320 с.

3. Барабошкин, А.Н. О микрораспределении тока на катоде при электролитическом выделении осадков с низкой электропроводностью [Текст] / А.Н. Барабошкин, М.И. Брейнин // Труды института электрохимии Уральского филиала АН СССР, 1986. - Вып. 11.

4. Бондарь, В.А. Особенности коррозии арматуры периодического профиля [Текст] / В.А. Бондарь // Известие вузов. Строительство. - 1992. - №4. - С. 114-115.

5. Бондарь, Л.В. Арматурный стержень как корродирующий элемент [Текст] / Л.В. Бондарь, В.А. Бондарь // Тези доповідей Міжнародної наук.-техн. конференції «Розвиток технічної хімії в Україні», 1-3 листопада, 1995. - Харків, 1995. - Вип. 1. - С. 205.

6. Кузнецов, Ю.Д. Особенности долговечности железобетонных конструкций при реконструкции промышленных предприятий [Текст] / Ю.Д. Кузнецов, И.Н. Заславский. - К.: Будівельник, 1985. - 112 с.

7. Москвин, В.М. Коррозия бетона и железобетона, методы их защиты [Текст] / В.М. Москвин, Ф.М. Иванов, С.Н. Алексеев, Е.А. Гузеев. - М.: Стройиздат, 1980. - 536 с.

8. Полак, А.Ф. Коррозия железобетонных конструкций зданий нефтяной промышленности [Текст] / А.Ф. Полак, В.Б. Ратинов, Г.Н. Гофман. - М.: Стойиздат, 1987. - 159 с.

9. Червоная, М.Е. Определение коррозионной стойкости арматуры [Текст] / М.Е. Червоная, А.С. Кошмат // Строительные материалы и конструкции. - 1986. - №4.

10. Феттер, К. Электрохимическая кинетика [Текст] / К. Феттер. - М.: Химия, 1967. - 176 с.

11. Zybura Adam. Opis elektrodyfuzyne procesu korjzji zbrojenia w zelbecie // Arch. inz. lad. 1989. - 35. №4. - p. 63-67.

Бондар Віктор Олександрович, д-р техн. наук, професор, кафедра технології будівельних конструкцій, виробів і матеріалів, Полтавський національний технічний університет ім. Юрія Кондратюка.

Бондар Людмила Вікторівна, канд. техн. наук, доцент, кафедра технології будівельних конструкцій, виробів і матеріалів, Полтавський національний технічний університет ім. Юрія Кондратюка.

Сушко Володимир Олексійович, старший викладач, кафедра технології будівельних конструкцій, виробів і матеріалів, Полтавський національний технічний університет ім. Юрія Кондратюка.

Bondar Viktor Oleksandrovych, doctor of technical science, professor, department of technology building designs, products and materials, Poltava national technical Yuri Kondratyuk university.

Bondar Ludmila Viktorovna, candidate of technical science, associate professor, department of technology building designs, products and materials, Poltava national technical Yuri Kondratyuk university.

Sushko Vladimir Alekseevich, senior lecturer, department of technology building designs, products and materials, Poltava national technical Yuri Kondratyuk university. 